\title{
Surface passivation and optical characterization of $\mathrm{Al}_{2} \mathrm{O}_{3} / \mathrm{a}-\mathrm{SiC}_{\mathrm{x}}$ stacks on $\mathrm{c}-\mathrm{Si}$ substrates
}

\author{
Gema López*, Pablo R. Ortega, Cristóbal Voz, Isidro Martín, Mónica Colina, \\ Anna B. Morales, Albert Orpella and Ramón Alcubilla
}

\section{Full Research Paper}



Beilstein J. Nanotechnol. 2013, 4, 726-731.

doi:10.3762/bjnano.4.82

Received: 12 July 2013

Accepted: 17 October 2013

Published: 06 November 2013

This article is part of the Thematic Series "Energy conversion applications of atomic layer deposition".

Guest Editor: J. Bachmann

(C) 2013 López et al; licensee Beilstein-Institut.

License and terms: see end of document.

\begin{abstract}
The aim of this work is to study the surface passivation of aluminum oxide/amorphous silicon carbide $\left(\mathrm{Al}_{2} \mathrm{O}_{3} / \mathrm{a}-\mathrm{SiC}_{\mathrm{x}}\right)$ stacks on both p-type and n-type crystalline silicon (c-Si) substrates as well as the optical characterization of these stacks. $\mathrm{Al}_{2} \mathrm{O}_{3}$ films of different thicknesses were deposited by thermal atomic layer deposition (ALD) at $200{ }^{\circ} \mathrm{C}$ and were complemented with a layer of a-SiC $\mathrm{X}_{\mathrm{x}}$ deposited by plasma-enhanced chemical vapor deposition (PECVD) to form anti-reflection coating (ARC) stacks with a total thickness of $75 \mathrm{~nm}$. A comparative study has been carried out on polished and randomly textured wafers. We have experimentally determined the optimum thickness of the stack for photovoltaic applications by minimizing the reflection losses over a wide wavelength range (300-1200 nm) without compromising the outstanding passivation properties of the $\mathrm{Al}_{2} \mathrm{O}_{3}$ films. The upper limit of the surface recombination velocity $\left(S_{\text {eff,max }}\right)$ was evaluated at a carrier injection level corresponding to 1-sun illumination, which led to values below $10 \mathrm{~cm} / \mathrm{s}$. Reflectance values below $2 \%$ were measured on textured samples over the wavelength range of $450-1000 \mathrm{~nm}$.
\end{abstract}

\section{Introduction}

Surface passivation has become a relevant issue in high efficiency crystalline silicon (c-Si) solar cells. The importance is even increasing as thinner wafers are used to reduce the cost for photovoltaic applications [1]. Aluminum oxide $\left(\mathrm{Al}_{2} \mathrm{O}_{3}\right)$ grown by atomic layer deposition (ALD) is a good alternative for passivating both lightly and highly doped $\mathrm{n}$ - and also p-type
c-Si substrates [2-4]. The excellent passivation quality is due to a double effect: (i) chemical passivation that involves a low density of interface defects, $D_{\text {it }}\left(\approx 10^{11} \mathrm{eV}^{-1} \mathrm{~cm}^{-2}\right)$, and (ii) field-effect passivation due to a high negative fixed-charge density, $Q_{\text {fix }}\left(\approx 10^{12} \mathrm{~cm}^{-2}\right)$ [5-8], which acts as an electrostatic shielding and significantly reduces the density of one type of 
charge carrier at the interface $\mathrm{c}-\mathrm{Si} / \mathrm{Al}_{2} \mathrm{O}_{3}[9,10]$. In order to achieve the lowest surface recombination velocity $\left(S_{\text {eff }}\right)$, it is necessary to perfom a thermal treatment after deposition (postdeposition annealing) to activate the passivating properties of $\mathrm{Al}_{2} \mathrm{O}_{3}$ layers $[11,12]$. In a previous work [13] we showed that an annealing process for 10 to $20 \mathrm{~min}$ at temperatures between $350{ }^{\circ} \mathrm{C}$ and $400{ }^{\circ} \mathrm{C}$ is enough to obtain an excellent passivation on polished p-type c-Si substrates.

In this work, we complement our preceding work by studying the surface recombination velocity on both $\mathrm{n}$ - and p-type wafers (polished and randomly textured), which were passivated with $\mathrm{Al}_{2} \mathrm{O}_{3} / \mathrm{a}-\mathrm{SiC}_{\mathrm{x}}$ stacks. In previous works we demonstrated that an a-SiC $\mathrm{x}$ capping layer on the $\mathrm{Al}_{2} \mathrm{O}_{3}$ improves the laser contact formation on p-type c-Si solar cells in comparison to the typical laser fired contact (LFC) process [14,15]. Moreover, it is well known that the ALD deposition of $\mathrm{Al}_{2} \mathrm{O}_{3}$ has very low deposition rates. Inserting an $\mathrm{a}-\mathrm{SiC}_{\mathrm{x}}$ capping layer by PECVD technique can overcome this drawback. In this study, we have investigated different combinations of layers that provide good antireflection properties while maintaining a total film thickness of $75 \mathrm{~nm}$. In addition to the passivation, a high-quality antireflection coating (ARC) plays a vital role in highly efficient solar cells [16]. We have measured the reflectance over a wide wavelength range, 300-1200 nm, in order to determine the optimum layer thicknesses for the stack to be used as an ARC without compromising the surface passivation quality.

\section{Results and Discussion \\ Surface recombination results}

The passivation characteristics of the $\mathrm{c}-\mathrm{Si} / \mathrm{Al}_{2} \mathrm{O}_{3} / \mathrm{a}-\mathrm{SiC}_{\mathrm{x}}$ stacks were tested the deposition of $\mathrm{Al}_{2} \mathrm{O}_{3}$ and $\mathrm{a}-\mathrm{SiC}_{\mathrm{x}}$, and after a final post-deposition annealing process (Figure 1). Moderate $S_{\text {eff,max }}$ values were achieved for as-deposited $\mathrm{Al}_{2} \mathrm{O}_{3}$ layers with better results on polished than on randomly textured samples. This level of surface passivation can be explained by the relatively low $D_{\text {it }}\left(\approx 10^{11} \mathrm{eV}^{-1} \mathrm{~cm}^{-2}\right)$ prior to the annealing step [17,18], which is responsible for the chemical passivation. The higher

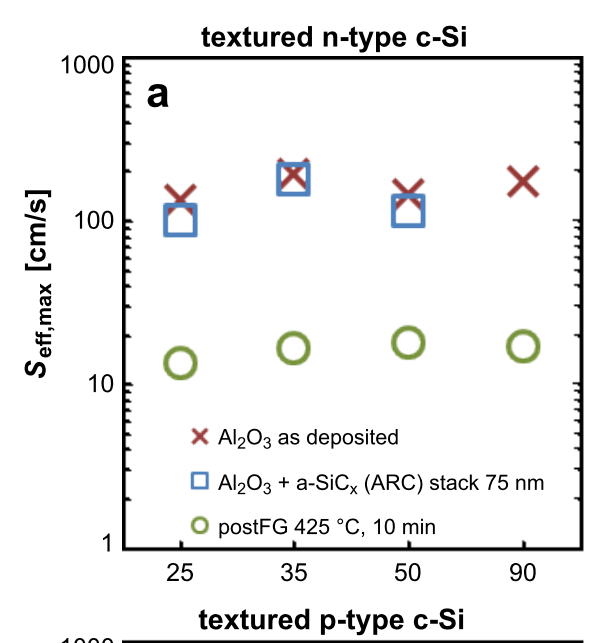

polished n-type c-Si

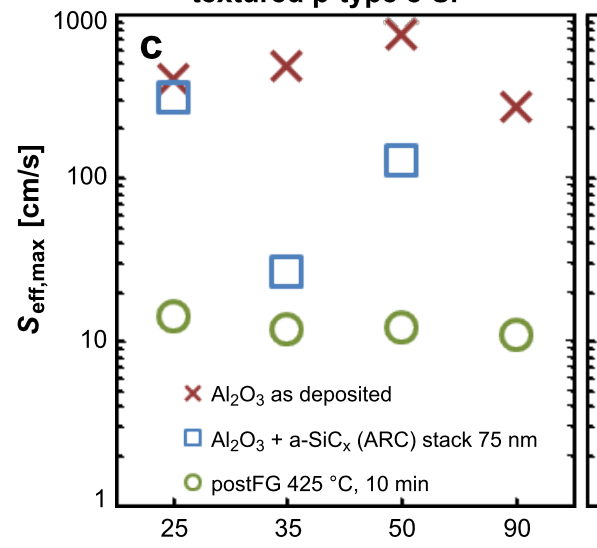

b

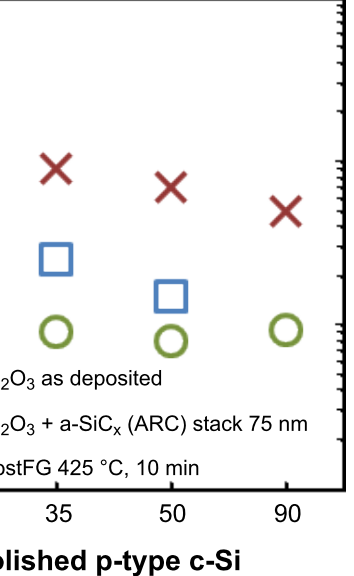

polished p-type c-Si

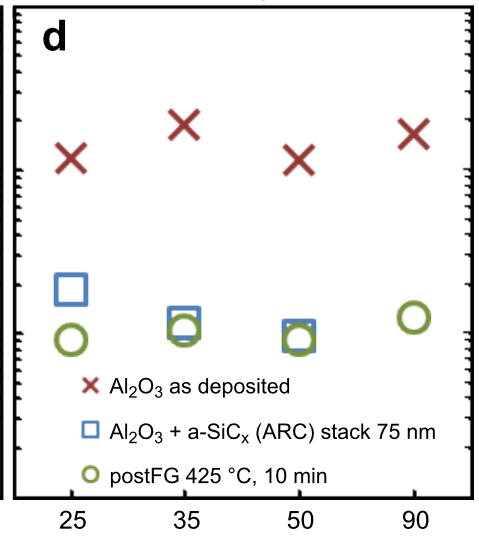

$\mathrm{Al}_{2} \mathrm{O}_{3}$ film thickness [nm]

Figure 1: Surface recombination velocity, $S_{\text {eff,max }}[\mathrm{cm} / \mathrm{s}]$. (a) and (b) $S_{\text {eff,max }}$ for randomly textured and polished n-type wafers respectively. (c) and (d) $\mathrm{S}_{\text {eff,max }}$ for randomly textured and polished p-type wafers respectively. $\mathrm{S}_{\text {eff,max }}$ was determined at 1 -sun injection level as a function of the $\mathrm{Al}_{2} \mathrm{O}_{3}$ thickness. The aluminum oxide layers were complemented up to $75 \mathrm{~nm}$ with an a-SiC film. $_{\mathrm{r}}$. 
$S_{\text {eff,max }}$ results obtained on textured samples $(>130 \mathrm{~cm} / \mathrm{s})$ could be attributed to a higher surface area due to the pyramid-shaped surface and a higher $D_{\text {it }}$ value on the exposed $\{111\}$ planes [1921]. Regarding the field-effect passivation, it has been reported that $\mathrm{ALD} \mathrm{Al}_{2} \mathrm{O}_{3}$ films exhibit a low $Q_{\text {fix }}$ present at the c-Si/ $\mathrm{Al}_{2} \mathrm{O}_{3}$ interface $\left(\approx 10^{11} \mathrm{~cm}^{-2}\right)$ prior to the annealing step [18]. Under these conditions, the electrostatic shielding of the interface does not induce an increase of the $\tau_{\text {eff }}$ value and the effect of the chemical passivation becomes more determinant. After the $\mathrm{a}-\mathrm{SiC}_{\mathrm{x}}$ deposition by PECVD, we observe in general a considerable improvement of the $S_{\text {eff,max }}$ parameter. Values close to $10 \mathrm{~cm} / \mathrm{s}$ were achieved on polished $\mathrm{n}$ - and p-type samples. This effect can be attributed to a small in-situ annealing effect that takes place in the PECVD chamber (deposition temperature $T_{\text {dep }}=300{ }^{\circ} \mathrm{C}$ ). The improvement of the passivation quality after an annealing step has been widely reported $[3,7,18,22]$, and it has been related to a lower $D_{\text {it }} \leq 1 \times 10^{11} \mathrm{eV}^{-1} \mathrm{~cm}^{-2}$ [17] combined with a higher concentration of fixed negative charges. The presence of these charges provides an electrostatic shielding due to a built-in electric field at the $\mathrm{c}-\mathrm{Si} / \mathrm{Al}_{2} \mathrm{O}_{3}$ interface $[4,23]$. Here, we also see that textured substrates showed higher $S_{\text {eff }}$ values after the $\mathrm{SiC}_{\mathrm{x}}$ deposition.

The final annealing treatment at $T_{\text {ann }}=425{ }^{\circ} \mathrm{C}$ for $10 \mathrm{~min}$ in forming gas improved the surface passivation, which led to a significant decrease in $S_{\text {eff,max }}$ for most of the samples. As a result, outstanding $S_{\text {eff,max }}$ values of less than $10 \mathrm{~cm} / \mathrm{s}$, i.e., $\tau_{\text {eff }}(1$ sun $)>1.3 \mathrm{~ms}$, were achieved independently of doping and surface morphology. We have to note that the final values on randomly textured substrates were quite similar to those of polished ones. Thus, the annealing temperature is a crucial parameter to activate the surface passivation and it should be higher for textured samples $\left(T_{\mathrm{ann}}=425{ }^{\circ} \mathrm{C}\right)$ than that found for polished substrates in a previous work $\left(T_{\mathrm{ann}}=375^{\circ} \mathrm{C}\right)$ [13]. In fact, some polished samples already showed an optimum passivation quality just after the PECVD process. On the other hand, an annealing temperature of $425^{\circ} \mathrm{C}$ is a critical limit to avoid a blistering effect, which we have observed on polished samples with a $90 \mathrm{~nm}$ thick $\mathrm{Al}_{2} \mathrm{O}_{3}$ layer. The blistering effect consists in a partial delamination of the $\mathrm{Al}_{2} \mathrm{O}_{3}$ film and the corresponding bubble formation. It is caused by a gaseous desorption where the layer acts as a gas barrier. The density and dimensions of the bubbles are directly related to the annealing and the ALD process temperatures and the thickness of the $\mathrm{Al}_{2} \mathrm{O}_{3}$ layer $[13,24,25]$.

Regarding the effect of the film thickness, it is interesting to note that a rather constant high level of surface passivation is obtained after the annealing for the whole range of $\mathrm{Al}_{2} \mathrm{O}_{3}$ thicknesses. The field-effect passivation remains constant indepen- dently of the thickness of the alumina layer probably because fixed negative charges seem to be located at the interface between $\mathrm{Al}_{2} \mathrm{O}_{3}$ and $\mathrm{c}-\mathrm{Si}$ [6]. Other authors have demonstrated that a thin interfacial $\mathrm{SiO}_{\mathrm{x}}$ layer between the c-Si and the $\mathrm{Al}_{2} \mathrm{O}_{3}$ film and generated during the $\mathrm{Al}_{2} \mathrm{O}_{3}$ deposition process, plays an important role in the formation of the negative fixed-charge density [26-30].

\section{Optical properties of $\mathrm{Al}_{2} \mathrm{O}_{3}$ and the $\mathrm{Al}_{2} \mathrm{O}_{3} / \mathrm{a}$ - $\mathrm{SiC}_{\mathrm{x}}$ stack}

The refractive index of $\mathrm{Al}_{2} \mathrm{O}_{3}$ measured by ellipsometry was around 1.6 at a wavelength of $632 \mathrm{~nm}$, whereas for the $\mathrm{a}-\mathrm{SiC}_{\mathrm{x}}$ layers it was quite close to 2.0. On the other hand, the absorbance of $\mathrm{Al}_{2} \mathrm{O}_{3} / \mathrm{a}-\mathrm{SiC}_{\mathrm{x}}$ stacks deposited on borosilicate glass was analyzed by means of an UV-vis-NIR Spectrometer equipped with an integrating sphere in the wavelength range from 300 to $600 \mathrm{~nm}$. The stack absorbance was calculated from the reflectance and transmittance measurements following Equation 1 and Equation 2,

$$
A_{\mathrm{L}}(\%)=100-T_{\mathrm{L}+\mathrm{G}}-R_{\mathrm{L}+\mathrm{G}}-A_{\mathrm{G}}
$$

$$
A_{\mathrm{G}}(\%)=100-T_{\mathrm{G}}-R_{\mathrm{G}},
$$

where $A$ is the absorbance, $T$ the transmittance and $R$ the reflectance. The subscritps $\mathrm{L}$ and $\mathrm{G}$ correspond to the layer stack and glass respectively. The results of the absorbance measurements are shown in Figure 2.

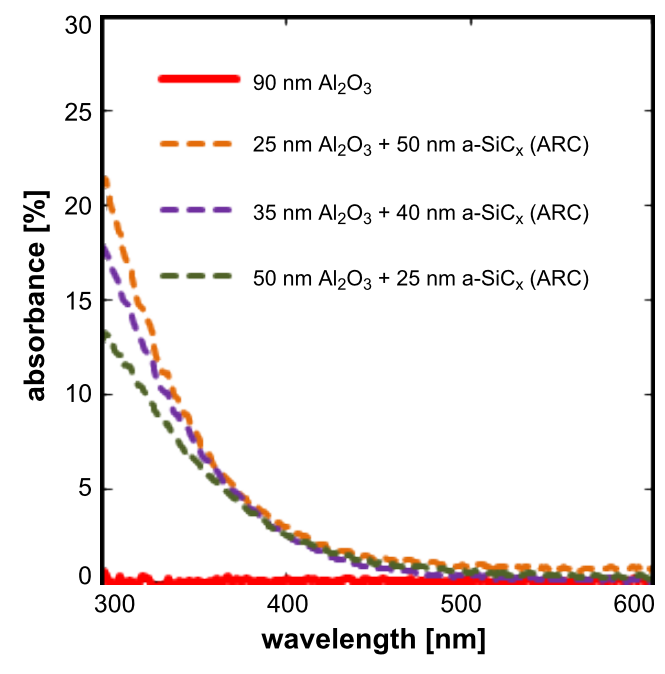

Figure 2: Absorbance as a function of the wavelength in the range from 300 to $600 \mathrm{~nm}$. Dashed lines belong to stacks with different $\mathrm{Al}_{2} \mathrm{O}_{3}$ thicknesses while the continuous red line is the absorbance of $90 \mathrm{~nm}$ $\mathrm{Al}_{2} \mathrm{O}_{3}$. 
Other works have previously reported an optical bandgap of $E_{\text {opt }}=6.4 \pm 0.1 \mathrm{eV}$ for as-deposited and annealed ALD $\mathrm{Al}_{2} \mathrm{O}_{3}$ films [18]. This means that this material is transparent for wavelengths above $200 \mathrm{~nm}$. Therefore, absorption of light by the $\mathrm{Al}_{2} \mathrm{O}_{3}$ layer does not occur in the wavelength range relevant for photovoltaic applications. For the sake of clarity, only the 300 to $600 \mathrm{~nm}$ wavelength range is depicted, i.e, in which a relevant absorbance can exist. However, it can be seen that as the a-SiC ${ }_{x}$ layer thickness increases, the optical absorbance also increases up to a value of $21.1 \%$ at $300 \mathrm{~nm}$. Thus, the $\mathrm{SiC}_{\mathrm{x}}$ capping layer is less attractive to be used as an antireflection layer on the illuminated side of the solar cell compared to a single $90 \mathrm{~nm} \mathrm{Al}_{2} \mathrm{O}_{3}$ film.

Reflectance measurements were also carried out. No significant differences were found between $\mathrm{n}$ and $\mathrm{p}$-type c-Si substrates. These measurements of single $\mathrm{Al}_{2} \mathrm{O}_{3}$ films as well as $\mathrm{Al}_{2} \mathrm{O}_{3}$ / $\mathrm{SiC}_{\mathrm{X}}$ stacks are shown in Figure 3.
The textured sample without ARC coating (black lines in Figure 3, left) exhibits an integrated average reflectance of $13.3 \%$, much lower than that of polished c-Si substrates. For a randomly textured surface, the reduced reflectance is explained by a second reflection of the incident light at the sidewalls of an opposite pyramid [31]. After coating the silicon substrates, the optical reflectance was further reduced.

When a $90 \mathrm{~nm} \mathrm{Al}_{2} \mathrm{O}_{3}$ film is deposited on a polished surface, the reflectance yields a minimum of $3.2 \%$ at a wavelength of about $600 \mathrm{~nm}$, but it increases quickly for shorter and longer wavelengths. Moreover, the reflectance properties become worse as the $\mathrm{Al}_{2} \mathrm{O}_{3}$ film thickness decreases. Next, the reflectance is strongly reduced when the polished samples are coated, but it still increases for longer wavelengths.

On the other hand, when a textured c-Si sample is coated by $90 \mathrm{~nm}$ of $\mathrm{Al}_{2} \mathrm{O}_{3}$ the reflectance values measured are below $2 \%$

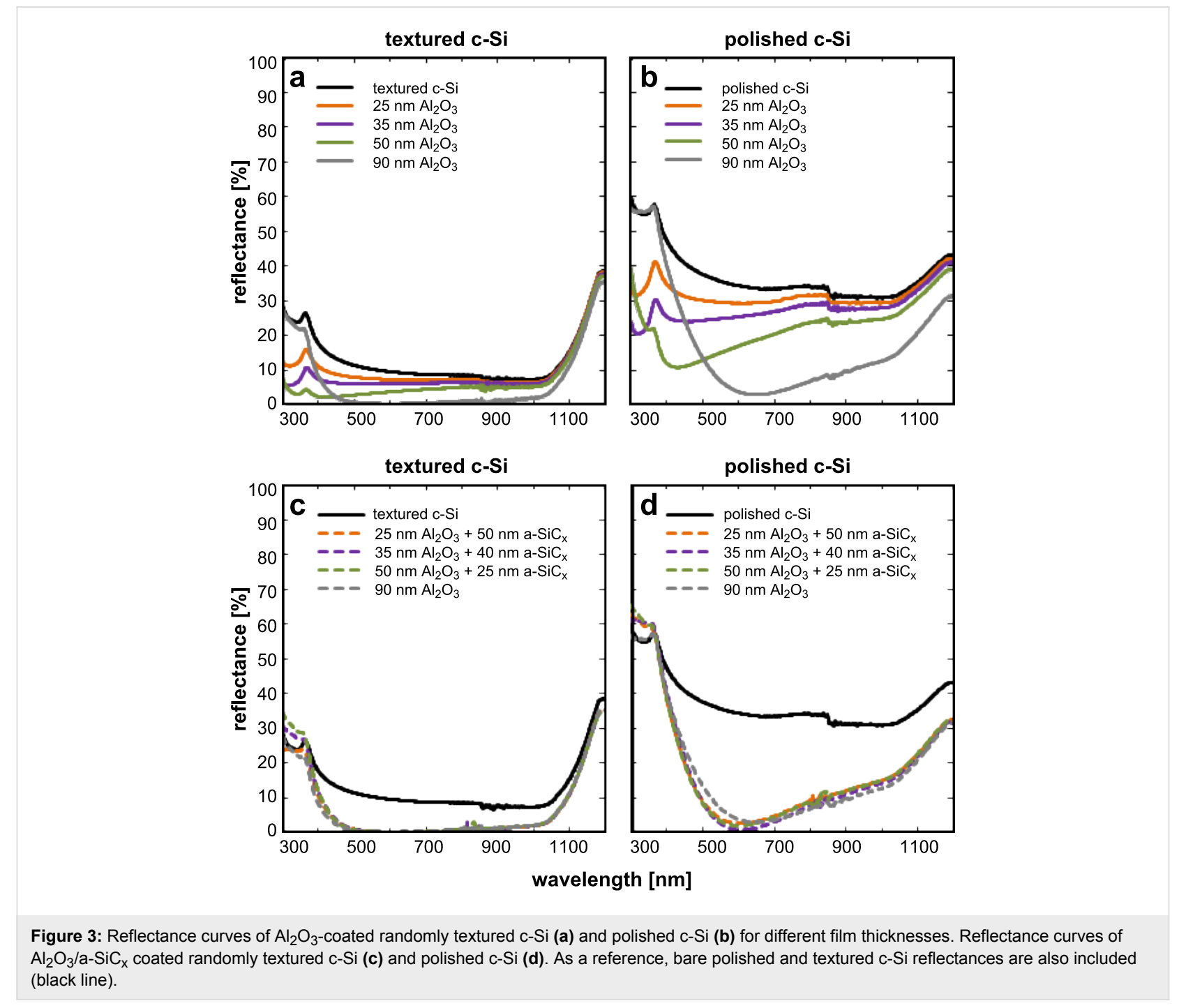


between 460 and $1000 \mathrm{~nm}$. Similar results were obtained with the textured samples coated by $75 \mathrm{~nm} \mathrm{Al}{ }_{2} \mathrm{O}_{3} / \mathrm{a}-\mathrm{SiC}_{\mathrm{x}}$ stacks. Thus, both $90 \mathrm{~nm} \mathrm{Al}{ }_{2} \mathrm{O}_{3}$ film and $75 \mathrm{~nm} \mathrm{Al}_{2} \mathrm{O}_{3} / \mathrm{a}-\mathrm{SiC}_{\mathrm{x}}$ stacks on textured surfaces are excellent anti-reflection options.

\section{Conclusion}

$\mathrm{Al}_{2} \mathrm{O}_{3}$ layers and $\mathrm{Al}_{2} \mathrm{O}_{3} / \mathrm{a}-\mathrm{SiC}_{\mathrm{x}}$ stacks with different thicknesses were deposited on polished and randomly textured p- and n-type c-Si substrates by combining thermal ALD and PECVD technique. Outstanding $S_{\text {eff,max }}$ values below about $15 \mathrm{~cm} / \mathrm{s}$ were achieved independently of the surface morphology and doping type of the samples. This value is low enough to obtain highly efficient c-Si solar cells. Concerning the optical properties, the absorbance of $\mathrm{Al}_{2} \mathrm{O}_{3}$ layers with different thicknesses and also of different $\mathrm{Al}_{2} \mathrm{O}_{3} / \mathrm{a}-\mathrm{SiC}_{\mathrm{x}}$ stacks was calculated by evaluating reflectance and transmittance measurements. We found that the absorption loss in $\mathrm{a}-\mathrm{SiC}_{\mathrm{X}}$ layers in the range of short wavelengths of is the reason for the superior overall optical performance of a single $90 \mathrm{~nm}$ thick $\mathrm{Al}_{2} \mathrm{O}_{3}$ film. Therefore, the latter represents the better option as an antireflection coating compared to $\mathrm{Al}_{2} \mathrm{O}_{3} / \mathrm{a}-\mathrm{SiC}_{\mathrm{x}}$ stacks. This result is supported by the reflectance measurements of $\mathrm{Al}_{2} \mathrm{O}_{3}$ films with different thicknesses and $\mathrm{Al}_{2} \mathrm{O}_{3} / \mathrm{a}-\mathrm{SiC}_{\mathrm{x}}$ stacks on polished and textured c-Si substrates in the wavelength range from 300 to $1200 \mathrm{~nm}$. In any case, the measured reflectance was less than $2 \%$ for all the $\mathrm{Al}_{2} \mathrm{O}_{3} / \mathrm{a}-\mathrm{SiC}_{\mathrm{X}}$ stacks and also for the single $90 \mathrm{~nm}$ layer of $\mathrm{Al}_{2} \mathrm{O}_{3}$. Nevertheless, an a-SiC $\mathrm{C}_{\mathrm{x}}$ capping layer could be useful if the $\mathrm{Al}_{2} \mathrm{O}_{3}$ layer needs to be protected from some chemical treatment during the solar cell fabrication. Moreover, on the rear side of a c-Si solar cell, where the optical absorbance is not critical, an $\mathrm{a}-\mathrm{SiC}_{\mathrm{X}}$ layer on top of the passivated $\mathrm{Al}_{2} \mathrm{O}_{3}$ film acts as a back reflector that reflects photons towards the bulk. This a-SiC $\mathrm{C}_{\mathrm{x}}$ capping layer on the $\mathrm{Al}_{2} \mathrm{O}_{3}$ also improves the laser contact formation on $\mathrm{p}$-type c-Si solar cells.

In summary, we can conclude that a $90 \mathrm{~nm} \mathrm{Al}_{2} \mathrm{O}_{3}$ film on textured c-Si substrates results in a good scheme for both passivation and anti-reflection coating on the illuminated side of highly efficient solar cells, whereas an $\mathrm{a}-\mathrm{SiC}_{\mathrm{X}}$ capping layer on $\mathrm{Al}_{2} \mathrm{O}_{3}$ films on the rear side of the solar cell provides better back contacts and a better back reflector scheme.

\section{Experimental}

As starting material, $\mathrm{n}$ - and p-type $(2.5 \pm 0.3 \Omega \mathrm{cm}) \mathrm{FZ}$ silicon(100) wafers with a thickness of approximately $290 \mu \mathrm{m}$ were used. One p-type and one n-type wafer were textured on both sides with solution of tetramethylammonium hydroxide (TMAH) in isopropanol (IPA) solution. Before film deposition, four wafers, two n-type (one textured and one polished) and two p-type (one textured and one polished) were cleaned following an RCA sequence and cut to quarters. $\mathrm{Al}_{2} \mathrm{O}_{3}$ films were subsequently deposited by thermal ALD (Savannah S200, Cambridge Nanotech; Cambridge, MA, USA) at $T_{\text {dep }}=200{ }^{\circ} \mathrm{C}$. This technique is based on sequential, self-limiting chemical reactions at the surface. The surface of the substrate is exposed to the precursor gases in alternating manner. The reactions are cyclical and after each reaction, there is a purge with $\mathrm{N}_{2}$. The typical ALD cycle to deposit $\mathrm{Al}_{2} \mathrm{O}_{3}$ layers consists of the injection into the chamber of trimethylaluminum $\left(\mathrm{Al}\left(\mathrm{CH}_{3}\right)_{3}\right)$ for $15 \mathrm{~ms}$ followed by $\mathrm{N}_{2}$ purging and the injection of water vapour for $50 \mathrm{~ms}$ followed by $\mathrm{N}_{2}$ purging. The precursor doses and exposure times were chosen such that all films were deposited under saturated self-limiting conditions leading to a film growth of $1.1 \AA$ /cycle. On each sample, belonging to a different type of wafer, films with a thickness of 25, 35, 50 and $90 \mathrm{~nm}$, respectively, were deposited (deposition times of 38, 53, 73 and 137 min respectively). On top of these films, we deposited an amorphous silicon carbide $\left(\mathrm{a}-\mathrm{SiC}_{\mathrm{x}}\right)$ film by PECVD that uses silane $\left(\mathrm{SiH}_{4}\right)$ and methane $\left(\mathrm{CH}_{4}\right)$ as precursor gases. The thicknesses of these a- $\mathrm{SiC}_{\mathrm{x}}$ films were 50,40 and $25 \mathrm{~nm}$, respectively (deposition times of $12 \mathrm{~min} 50 \mathrm{sec}, 10 \mathrm{~min} 15 \mathrm{sec}$ and $6 \mathrm{~min}$ $24 \mathrm{sec}$, respectively) in order to complement the 25,35 and $50 \mathrm{~nm} \mathrm{Al}{ }_{2} \mathrm{O}_{3}$ films for a total stack thickness of $75 \mathrm{~nm}$. Substrates with an $\mathrm{Al}_{2} \mathrm{O}_{3}$ thickness of $90 \mathrm{~nm}$ were also studied without any $\mathrm{a}-\mathrm{SiC}_{\mathrm{x}}$ capping layer. A post-deposition annealing process in a forming gas environment $\left(\mathrm{H}_{2} / \mathrm{N}_{2}\right)$ at $425{ }^{\circ} \mathrm{C}$ for $10 \mathrm{~min}$ was done to activate the passivation properties. All these substrates were symmetrically covered to measure the effective lifetime $\tau_{\text {eff }}$ by measuring the quasi-steady-state photoconductance (QSSPC) with a Wafer Lifetime Tester Sinton WCT-100 $[32,33]$. The upper limit of the surface recombination velocity $\left(S_{\text {eff,max }}\right)$ was deduced from the effective lifetime $\tau_{\text {eff }}$ measurements as a function of the excess carrier density $(\Delta n)$ at 1 sun injection level as

$$
S_{\text {eff,max }}=\frac{W}{2 \tau_{\text {eff }}}
$$

where $W$ is the substrate thickness and an infinite bulk lifetime has been assumed.

Concerning the optical characterization, the thickness and refractive index of the individual $\mathrm{Al}_{2} \mathrm{O}_{3}$ and $\mathrm{SiC}_{\mathrm{x}}$ layers were measured by ellipsometry (Plasmos SD 2100) at a wavelength of $632 \mathrm{~nm}$. Finally, in order to know the optical absorbance, we also deposited the same $\mathrm{Al}_{2} \mathrm{O}_{3} / \mathrm{a}-\mathrm{SiC}_{\mathrm{x}}$ stacks on transparent substrates (Borosilicate glass). The reflectance (diffuse and specular) and the transmittance were measured in the wavelength range from 300 to $1200 \mathrm{~nm}$ by using a UV-visible-NIR spectrometer (Shimadzu 3600) equipped with an ISR 3100 integrating sphere. 


\section{Acknowledgements}

This work has been supported by the Spanish Ministry of Science and Innovation under projects ENE2010-21384-C0404, TEC2011-26329 and INNDISOL IPT-420000-2010-6 (FEDER funded "Una manera de hacer Europa").

\section{References}

1. Hofmann, M.; Janz, S.; Schmidt, C.; Kambor, S.; Suwito, D.; Kohn, N.; Rentsch, J.; Preu, R.; Glunz, S. W. Sol. Energy Mater. Sol. Cells 2009, 93, 1074-1078. doi:10.1016/j.solmat.2008.11.056

2. Hoex, B.; Van de Sanden, M. C. M.; Schmidt, J.; Brendel, R.; Kessel, W. M. M. Phys. Status Solidi RRL 2012, 6, 4-6. doi:10.1002/pssr.201105445

3. Agostinelli, G.; Delabie, A.; Vitanov, P.; Alexieva, Z.; Dekkers, H. F. W.; De Wolfa, S.; Beaucarne, G. Sol. Energy Mater. Sol. Cells 2006, 90, 3438-3442. doi:10.1016/j.solmat.2006.04.014

4. Hoex, B.; Schmidt, J.; Bock, R.; Altermatt, P. P.; van de Sanden, M. C. M.; Kessels, W. M. M. Appl. Phys. Lett. 2007, 91, 112107. doi:10.1063/1.2784168

5. Werner, F.; Veith, B.; Tiba, V.; Poodt, P.; Roozeboom, F.; Brendel, R.; Schmidt, J. Appl. Phys. Lett. 2010, 97, 162103. doi:10.1063/1.3505311

6. Dingemans, G.; Seguin, R.; Engelhart, P.; van de Sanden, M. C. M.; Kessels, W. M. M. Phys. Status Solidi RRL 2010, 4, 10-12. doi:10.1002/pssr.200903334

7. Seguini, G.; Cianci, E.; Wiemer, C.; Saynova, D.; van Rossmalen, J. A. M. Appl. Phys. Lett. 2013, 102, 131603. doi:10.1063/1.4800541

8. Liao, B.; Stangl, R.; Mueller, T.; Lin, F.; Bhatia, C. S.; Hoex, B. J. Appl. Phys. 2013, 113, 024509. doi:10.1063/1.4775595

9. Hoex, B.; Schmidt, J.; Pohl, P.; van de Sanden, M. C. M.; Kessels, W. M. M. J. Appl. Phys. 2008, 104, 044903. doi:10.1063/1.2963707

10. Terlinden, N. M.; Dingemans, G.; van de Sanden, M. C. M.; Kessels, W. M. M. Appl. Phys. Lett. 2010, 96, 112101. doi:10.1063/1.3334729

11. Rafí, J. M.; Zabala, M.; Bedarrain, O.; Campabadal, F. J. Electrochem. Soc. 2011, 158, G108-G114. doi:10.1149/1.3559458

12. Frascaroli, J.; Seguini, G.; Cianci, E.; Saynova, D.; van Roosmalen, J.; Perego, M. Phys. Status Solidi A 2013, 210, 732-736. doi:10.1002/pssa.201200568

13. Lopez, G.; Ortega, P.; Voz, C.; Martín, I.; Colina, M.; Orpella, A.; Alcubilla, $\mathrm{R}$. Optimization of $\mathrm{Al}_{2} \mathrm{O}_{3}$ films obtained by ALD to passivate p-type c-Si wafers. In Proccedings of the 27th European Photovoltaic Solar Energy Conference and Exhibition, Frankfurt, Sept 24-28, 2012; Germany, 2012.

14. Ortega, P.; Martín, I.; López, G.; Colina, M.; Orpella, A.; Voz, C.; Alcubilla, R. Sol. Energy Mater. Sol. Cells 2012, 106, 80-83. doi:10.1016/j.solmat.2012.05.012

15. Martín, I.; Ortega, P.; Colina, M.; Orpella, A.; López, G.; Alcubilla, R. Prog. Photovoltaics 2012, 21, 1171-1175. doi:10.1002/pip.2207

16. Green, M. A. Higher Efficiency Silicon Solar cells; Trans. Tech. Pub.: Aedermannsdorf, Switzerland, 1987.

17. Dingemans, G.; Terlinden, N. M.; Pierreux, D.; Profijt, H. B.; van de Sanden, M. C. M.; Kessels, W. M. M. Electrochem. Solid-State Lett. 2011, 14, H1-H4. doi:10.1149/1.3501970

18. Dingemans, G.; Kessels, W. M. M. J. Vac. Sci. Technol., A 2012, 30, 040802. doi:10.1116/1.4728205
19. Mclntosh, K. R.; Johnson, L. P. J. Appl. Phys. 2009, 105, 124520. doi:10.1063/1.3153979

20. Angermann, H. Appl. Surf. Sci. 2008, 254, 8067-8074. doi:10.1016/j.apsusc.2008.03.022

21. Basore, P. A. IEEE Trans. Electron Devices 1990, 37, 337-343. doi:10.1109/16.46362

22. Benick, J.; Richter, A.; Hermle, M.; Glunz, S. W. Phys. Status Solidi RRL 2009, 3, 233-235. doi:10.1002/pssr.200903209

23. Hoex, B.; Schmidt, J.; Van de Sanden, M. C. M.; Kessels, W. M. M. Crystalline silicon surface passivation by negative-charge-dielectric $\mathrm{Al}_{2} \mathrm{O}_{3}$. Photov.Spec.Conf. PVSC 08, 33th IEEE, May 11-16, 2008; pp 1-4.

24. Vermang, B.; Goverde, H.; Lorenz, A.; Vereecke, G.; Meersschaut, J.; Corngliotti, E.; Rothschild, A.; John, J.; Poortmans, J.; Mertens, R. On the blistering of atomic layer deposited $\mathrm{Al}_{2} \mathrm{O}_{3}$ as $\mathrm{Si}$ surface passivation. Photov. Spec. Conf. PVSC11, 37th IEEE, June 19-24, 2011; pp 3562-3567.

25. Beldarrain, O.; Duch, M.; Zabala, M.; Rafí, J. M.; Bargalló González, M.; Campabadal, F. J. Vac. Sci. Technol., A 2012, 31, 01A128. doi:10.1116/1.4768170

26. Gielis, J. J. H.; Van de Sanden, M. C. M.; Kessels, W. M. M. J. Appl. Phys. 2008, 104, 073701. doi:10.1063/1.3658246

27. Dingemans, G.; Terlinden, N. M.; Verheijen, M. A.; van de Sanden, M. C. M.; Kessels, W. M. M. J. Appl. Phys. 2011, 110, 093715. doi:10.1063/1.3658246

28. Hoex, B.; Heil, S. B. S.; Langereis, E.; van de Sanden, M. C. M.; Kessels, W. M. M. Appl. Phys. Lett. 2006, 89, 042112. doi:10.1063/1.2240736

29. Hoex, B.; Gielis, J. J. H.; van de Sanden, M. C. M.; Kessels, W. M. M. J. Appl. Phys. 2008, 104, 113703. doi:10.1063/1.3021091

30. Lei, D.; Yu, X.; Song, L.; Gu, X.; Li, G.; Yang, D. Appl. Phys. Lett. 2011, 99, 052103. doi:10.1063/1.3616145

31. Zhao, J.; Green, M. IEEE Trans. Electron Devices 1991, 38 , 1925-1934. doi:10.1109/16.119035

32. Sinton, R. A.; Cuevas, A. Appl. Phys. Lett. 1996, 69, 2510. doi:10.1063/1.117723

33. Cuevas, A.; Macdonald, D. Sol. Energy 2004, 76, 255-262. doi:10.1016/j.solener.2003.07.033

\section{License and Terms}

This is an Open Access article under the terms of the Creative Commons Attribution License (http://creativecommons.org/licenses/by/2.0), which permits unrestricted use, distribution, and reproduction in any medium, provided the original work is properly cited.

The license is subject to the Beilstein Journal of Nanotechnology terms and conditions: (http://www.beilstein-journals.org/bjnano)

The definitive version of this article is the electronic one which can be found at:

doi:10.3762/bjnano.4.82 